\title{
水理構造物の諸問題
}

(シェル形長径間ゲートの流体関連振動)

\section{Vibration Problems in Hydraulic Structures}

(Flow-Induced Vibration of Shell-Type Long-Span Gates)

$\begin{array}{ll}\text { 石井徳章*1 } & \text { 中田亮生*2 } \\ \text { Noriaki ISHII } & \text { Akinori NAKATA }\end{array}$

Results from a field study of the flow-induced vibrations of a full-scale, long-span, shell-type gate undergoing simultaneous over- and underflow are presented. Data include experimentally determined mode shapes and frequencies for both horizontal and vertical bending modes, the maximum center-span vibration amplitudes in the horizontal and vertical direction as functions of underflow gate openings and overflow depths, and the trajectories of gate motion. Predictions of gate vibration, based on theories previously developed from model-scale data, were in good agreement with the experimentally observed behavior. Several subjects for future study are also presented in this study.

1.はじめに 水理構造物としては、水をせき止 めるための水門が代表的なものとして上げられる。テ ンタゲート（ラジアルゲート、扇形ゲートとも呼ばれ る）、長径間ゲート、シェル形長径間ゲートなど、小 形のものから大形のものまで様々である ${ }^{1)}$ 。大形のも のでは総重量が40tonに達するものもある。そのような 大形のゲートも、水のカによっていとも簡単に自励振 動を引き起こす埸合がある。もちろんのこと、大形の 構造物が振動した場合にはぜい性破壊、座屈破壊など の深刻な問題につながる可能性がでてくるので、設計 者は振動問題には非常に神経質になる。しかしながら、 水と関連した振動であるために、それらの理論的な解 析が極めて難しい場合が多く、それだけに十分な資料 も明らかにされていないため、設計段階で自励振動の 可能性を十分に検討するのが困難な場合が多い。むち ろん、いろいろな埸合についてモデルを用いた実験を 行って詳しいデー夕をとれば、その個々の場合につい ての特性は確かに正確に把挃することができる。しか しながら、それだけでは現象を支配する力学的相似則 や本質的な振動発生メカニズムを明らかにすることが どうしてもできない。したがって、少し設計が変わっ た場合の対応、振動を防止するための最善の方法の検 郡などが進められないことになる。このような意味か らも、理論的な解析の必要性が非常に高い、と言える。 水に限らず空気と関連した場合にむ、權造物の振動 には渦の発生が関与してくる場合（渦励起型振動）が 多く、したがっていずれの水理構造物の流体関連振動 も完全に理論的に解くことは非常に難しいとされてき
た（事実、実験的な研究報告例が大半である）。理論 的に解こうとする努力すら、長年にわたって放㧛され てきたようにも思われる。そのような中にあって、筆 者らは、渦に全く無関係なタイプの振動問題がまだま だ多く残されていることに注目し、理論的な解析を試 み、モデル実鈳による検钲を繰り返してきた。

図 1 に示すテンタゲートの場合、ゲートを少し引き 上げて微小な下端放水を開始すると、ゲートはトラニ オンピンの周りに做しい自励振動を引き起こす 2 〜。 。 下流例が水没していない場合には、渦は全く発生しな いので、ポテンシャル理論を用いて流れ場を理論的に 解くことができ、ゲートの振動特性を理論的に明らか にすることができた。結果はモデル実験を用いた結果

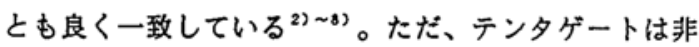
常用洪水吐ゲートとして用いられるので、建設省の笡 重な管理下にあり、そのため振動に関する実地調查を

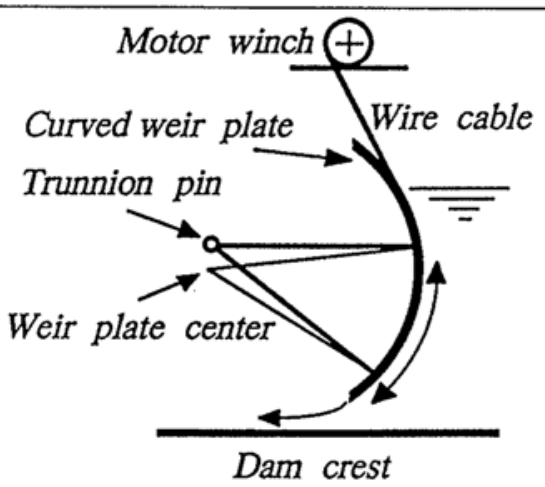

Fig.1 Cross-sectioal view of a tainter-gate
*1大阪電気通侮大学・工学部・教授

Professor, Osaka Electro-Communication Univ.

\section{*2大阪霨気通僧大学・大学院・博士課程}

Graduate Student, Osaka Electro-Communication Univ. 


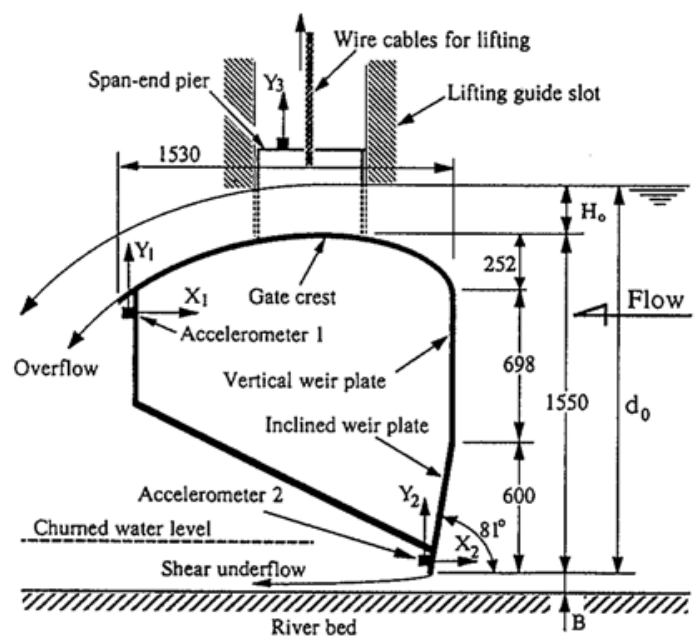

Fig.2 Cross-sectioal view of the full-scale gate (All linear dimensions in mm)

行うことが非常にむつかしいのが現状である。したが って、実機の実測值との対応は、未だ確認されていな い。

一方、図 2 に示すシェル形長径間ゲートに関しては、 径間が 24.6 、総重量が26.49tonの実機について振動に 関する実地調查を1988年に行うことができたの。この 場合の流れ場にも瀜が全く発生しないので、理論的な 解析が可能なはずである。こういった観点から理論的 な解析も試みている。したがって、水理構造物の中で も特にシェル形長径間ゲートは、実測との対応および 今後の課題について䔀論できる数少ない題材の一つで あるといえる。ここでは、実用されているシェル形長 径間ゲートの自励振動問題に関して、実測の結果、理 論解析の一例および実測との対応について説明し、今 後の課題についても触れたい。

2.シェル形長径間ゲート

幅の広い川の流れを せき止める農業用灌溉設備として、背丈の低い長径間 ゲートが利用されている。断面は図 2 に示すようにシ ェル形である。径間の長さは $24.64 \mathrm{~m} 、$ 質量は $26,492 \mathrm{~kg}$ である。クレスト（上部）は水を越流させるためにな めらかな曲線で作られ、ゲートの前面は鈶直なせき板 と倾斜したせき板から構成される。この種のゲートの 最も注目すべき特徵は、ゲートの縦横比が大体 1 対 1 であるために、水平と上下の 2 方向に曲げ振動の自由 度を持つ点である。

\section{3、実地調查結果 この種のゲートは河休上まで}

下ろして使用するのが普通である。しかし、上流侧の 水位を調節するコントロールゲートとしても使える可 能性を検㷉するために、ゲートを少し吊り上げて微小 な下端放水と大きな越流を同時に行った。そのとき、 ゲートの下流侧に閉じた空間が形成されないようにし

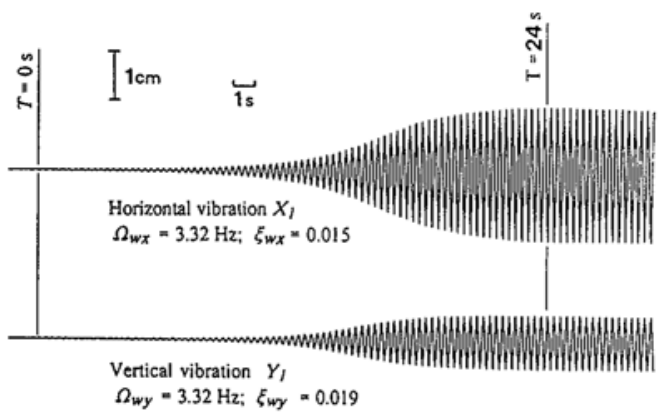

Fig.3 Waveforms of transient vibrations in both the horizontal and vertical directions, measured at a point just under the gate crest tail in the spanwise middle of the gate

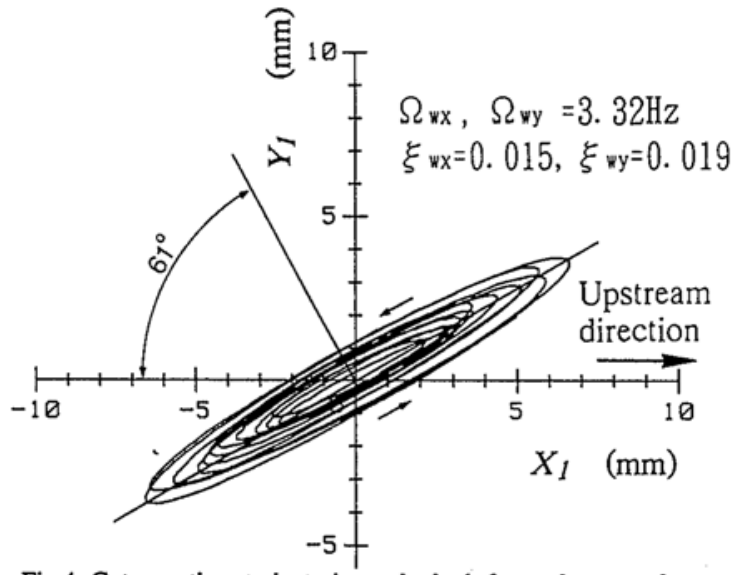

Fig.4 Gate motion trajectories calculatd from the waveforms growing exponencially

ているにもかかわらず、ゲートが激しい自励振動を引 き起こした（この種の振動問題に関しては、モデル実 験でその特性を詳しく娚へている(0)（11)）。ゲート開 度 $\mathrm{B}$ を $5 \sim 7 \mathrm{~cm}$ の範囲に設定したときに、自励振動が 観測され、 $B=5 \mathrm{~cm}$ のき、もっとも激しい自励振動 が発生した。そのときの振動波形を図 3 に示す。ゲー 卜は静止した状態から自然に振動しはじめ、指数関数 的に成長して約 24 秒後には最大振幅に達し、その後、 同じ振幅で安定に振動を続けている。水平と上下の振 動数 $\Omega_{\mathrm{vx}}$ と $\Omega$ wは共に $3.32 \mathrm{~Hz}$ 、発振比（負性隇衰比）

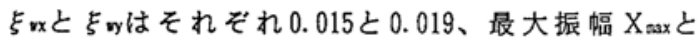
$\mathrm{Y}_{\max }$ はそれぞれ $13.8 \mathrm{~mm}$ と $5.1 \mathrm{~mm}$ であった。越流高さH。 （図 2 を参照）は25.0c以であった。これらの振動波形 を合成し、ゲートの運動軌跡を求めたものを図 4 に示 す。運動轨跡は、ゲートが下流侧に押されたときに放 水口を閉める、いわゆる「プレス・シャット型」にな っている。遇動軌跡の長手軸に対する法線は、水平な 軸から約 $61^{\circ}$ 傾いている。

ゲートの上流侧の中央を上・下流方向にハンマーで 衍慗的に加振し、曲げによる構造振動モードを調へた。 
Table.1 Comparison of theoretical values with experimental data for the full-scale gate

\begin{tabular}{|c|c|c|c|}
\hline & EXPERIMENT & $\begin{array}{l}\text { THEORY } \\
\text { using equivalent } \\
\text { gate height. } H_{\text {e }}\end{array}$ & $\begin{array}{c}\text { THEORY } \\
\text { using } \\
\text { physical gate height }\end{array}$ \\
\hline$\Omega_{a r}$ & $\begin{array}{c}4.69 \mathrm{~Hz} \\
(29.5 \mathrm{rad} / \mathrm{s})\end{array}$ & - & - \\
\hline$\Omega_{\infty x}$ & $\begin{array}{c}3.32 \mathrm{~Hz} \\
(20.9 \mathrm{rad} / \mathrm{s})\end{array}$ & $\begin{array}{c}3.30 \mathrm{~Hz} \\
(19.9 \mathrm{rd} / \mathrm{s})\end{array}$ & $\begin{array}{c}3.16 \mathrm{~Hz} \\
(19.85 \mathrm{rad} / \mathrm{s})\end{array}$ \\
\hline$\Delta M_{x}$ & $26,389 \mathrm{~kg}$ & $25,980 \mathrm{~kg}$ & $30,783 \mathrm{~kg}$ \\
\hline$\Delta C_{x}$ & $70.867 \mathrm{~N} /(\mathrm{m} / \mathrm{s})$ & $65.537 \mathrm{~N} /(\mathrm{m} / \mathrm{s})$ & $74.463 \mathrm{~N} /(\mathrm{m} / \mathrm{s})$ \\
\hline
\end{tabular}

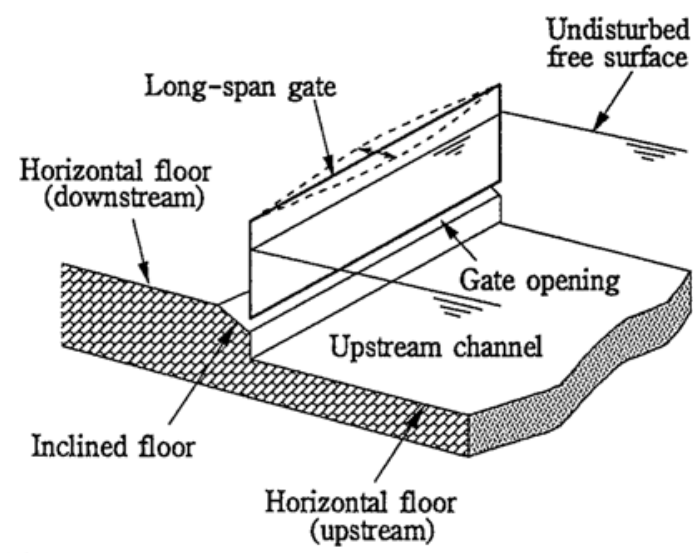

Fig.5 Cross-sectional view of a longitudinally slender long-span gate

伝達関数のピークの分布から、主要な振動モードを特 定した結果、基本となる振動モードはゲート両端を節 とする $1 / 2$ 波長の曲げ振動モードであり、固有振動数は $4.69 \mathrm{~Hz}$ であり、隇衰比は0.027であることが分かった。 ゲートの振動に伴って水が動くために、ゲートの加 速度に比例した流体力（慣性力）か生じる。さらに、 放水流量が変化する場合には、速度に比例した流体力 （加振力）も生じる。それぞれの比例係数が付加質量 $\Delta \mathrm{M} \times$ と流体発振係数 $\Delta \mathrm{C}_{x}$ である。実测した振動波形 (図 3) および空中での固有振動数と隇衰比からこれ らの $\Delta \mathrm{M} \times$ と $\Delta \mathrm{C}_{\mathrm{x}}$ を算出することができる。計算結果を それぞれ表 1 に示す。付加質量 $\Delta \mathrm{M}_{\mathrm{x}}$ はゲートの質量に 近い大きな値を示すことが分かる。

4. 理綸解析結果の応用および実測との対応 断面 が緃に細長い長径間ゲートが、図 5 に示すように、か け上がった河床の上に設置されていると、ゲートは流 水方向に激しい自励振動を引き起こす。著者らはこの 種の振動問題に関して理論的な解析 ${ }^{12) \sim 16)}$ を行い、特 に放水口開度が微小な場合の現象を支配する基本的な パラメータが基礎フルード数 Foおよび水とゲートとの

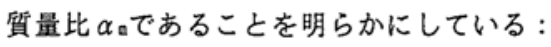

$$
\mathrm{F}_{0} \equiv \sqrt{\mathrm{d}_{0} / \mathrm{g}} \quad \Omega_{\mathrm{ax}}, \quad \alpha_{\mathrm{n}} \equiv \rho \mathrm{d}_{0}^{2} /(\mathrm{M} / \mathrm{L}) .
$$

ここで、 $\mathrm{d}_{0}$ は放水口の水深、 $\Omega_{\mathrm{ax}}$ は空中での固有网振 動数、M $/ \mathrm{L}$ はゲートの単位長さ当りの質最である。

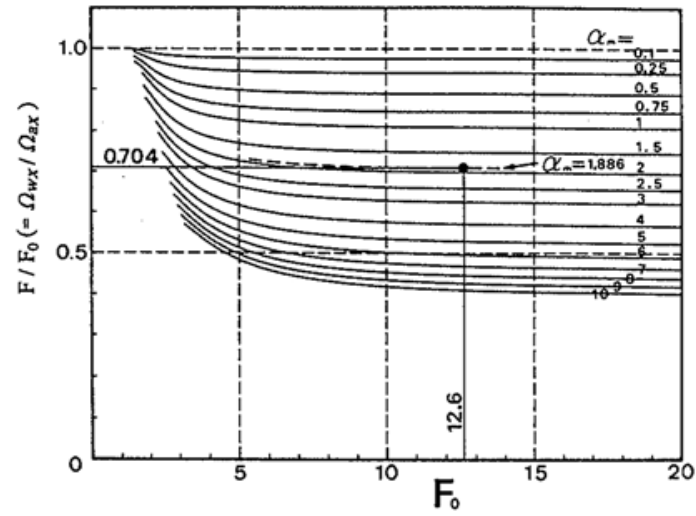

Fig.6 In-water to in-air vibration frequency ratio calculated from a theoretical study of a longitudinally slender long-span gate undergoing streamwise vibration

まず基碳フルード数 $\mathrm{F}_{0}$ と質量比 $\alpha_{\mathrm{a}}$ が分かると、図 6 から流水中での振動数 $\Omega_{\boldsymbol{n}}$ が分かり、フルード数F :

$$
\mathrm{F} \equiv \sqrt{\mathrm{d}_{0} / \mathrm{g}} \Omega_{\boldsymbol{x} x}
$$

が算出できる。Fの値が分かると、図 7 から付加質量 $\Delta \mathrm{M} \times$ と流体発振係数 $\Delta \mathrm{C}_{\mathrm{x}}$ が算出できる :

$$
\begin{aligned}
& \Delta \mathrm{m}_{\mathrm{b}} \equiv\left(\Delta \mathrm{M}_{\mathrm{x}} / \mathrm{L}\right) /\left(\rho \mathrm{d}_{0}^{2}\right), \\
& \Delta \mathrm{C}_{\mathrm{r}} \equiv\left(\Delta \mathrm{C}_{\mathrm{x}} / \mathrm{L}\right) /\left(\rho \mathrm{d}_{0} \sqrt{\left.\mathrm{g} \mathrm{d}_{0}\right)}\right.
\end{aligned}
$$

図7bに見られる $\mathrm{k}$ はゲートの傾き率 :

$\mathrm{k} \equiv \sqrt{2} \mathrm{c}_{\mathrm{f}} \cos \theta \quad$ ( $\mathrm{c}_{\mathrm{f}}:$ 動的な流量係数) (4) を表す。 $\theta$ は、図7bのさし絵に示すように、ゲートの 動く方向に対する法線と傾いた河床とのなす角度を表 し、ゲートの水平動に対して放水流量がどの程度変動 するかを決定する。したがって、さし絵のようにゲー ト真下の河床がかけ上がっている場合には k は正、逆 の場合には k は負となる。河床がか上かっている場 合、図7bから明らかなように、フルード数が小さいと きを除くほとんどの範囲で $\Delta \mathrm{cr}$ 的正となる。したがっ て、式( 3 )から $\Delta \mathrm{C}_{\mathrm{x}}$ む正となり、流体による正の励振 力が存在することになる。このことは、もし機械的な 減衰の効果が小さいならば、ゲートは必ず自励振動を 引き起こすといった非常に大切なことを示唆している。 上で説明した縦に細長い長径間ゲートの理論解析結 果は、シェル形長径間ゲートにも応用することが可能 である。縦に細長い長径間ゲートが水平方向に振動す ると、それによって水が押されたり引き込まれたりす るので流体圧力が変動する。その変動圧力の振幅を図 8 に示す。縦軸 $\mathrm{y}$ は放水口の水深 $\mathrm{d} 0$ で無次元化してい る（y=0 が水面、 $\mathrm{y}=-1$ かゲート下端に相当）。シ ェル形長径間ゲートのクレストの位置を $\mathrm{y}=-0.14$ の破 線で示すように、それよりも上の流体圧力は下方の流 体压力に比へてはるかに小さい。それゆえ、非常に粗 い取扱いではあるが、オーバーフローを有するシェル 

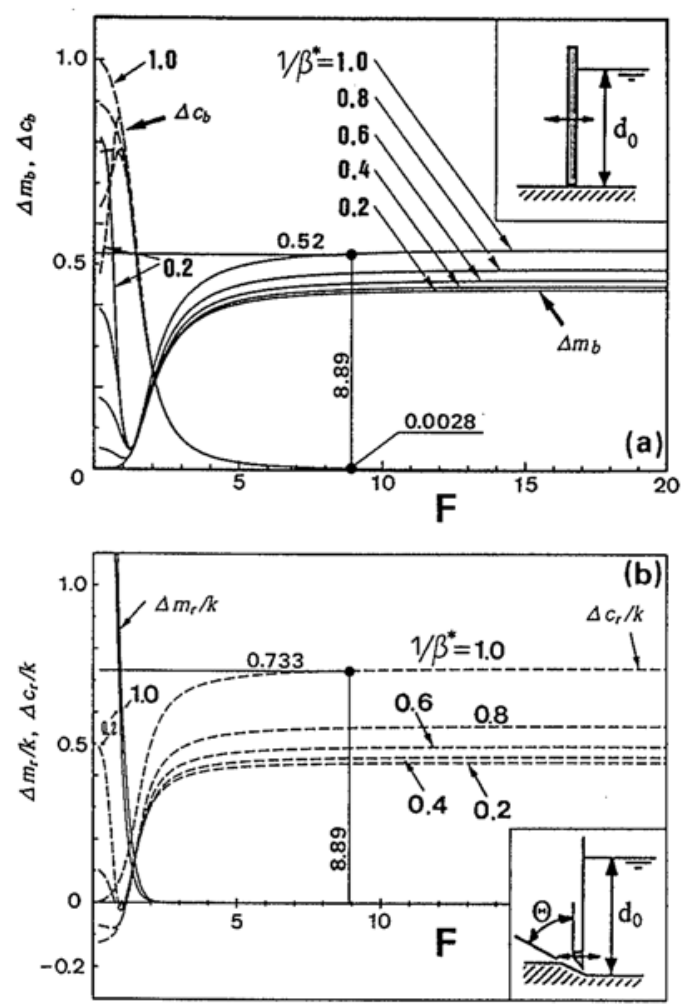

Fig.7 Reduced added mass, reduced fluid damping coefficient, and reduced fluid excitation coefficient calculated from a theoretical study of a longitudinally slender long-span gate undergoing streamwise vibration

形長径間ゲートが水平方向に振動することによって生 じる流体圧力を図 8 に示す $-0.14>\mathrm{y}>-1.0$ の範囲の計 算値で近似しても、大きな融りは生じないものと考え られる。このような観点に立つと、質量比 $\alpha$ 、付加質 量 $\Delta \mathrm{m}$ b、流体発振係数 $\Delta \mathrm{c}_{\mathrm{r}}$ の定義式にそれぞれ含まれ る $\mathrm{d} 0$ をシェル形長径間ゲートの高さHに置き換えるだ けで、図 6、7に示した理論解析結果がのまま利用 できる。そこで、 $\mathrm{H}=1.55 \mathrm{~m}$ 用いて流水中の振動数 $\Omega$ v 、付加質量 $\Delta \mathrm{M}$ 、流体発振係数 $\Delta \mathrm{C}_{\mathrm{x}}$ を算出した。 その結果を表 1 の右側の列に示す。左侧の列に示した 実測の結果と良く一致していることが分かる。さらに、 滑らかな曲線で作られたゲートクレストは付加質量を 隇少させる効果があると考えられるので、ゲートの高 さ $(1.55 \mathrm{~m})$ からゲートクレストの高さ $(0.252 \mathrm{~m})$ の半 分を差し引いた $1.424 m$ がゲートの有効高さであるとし て取り扱うと、表 1 の真中の列に計算結果を示すよう に、実測値と非常に良く一致する結果が得られる。

5. 今後の課題実地調查を行った図 2 に示すゲ 一トではゲート下部の傾斜したせき板がかなり切り立 っているために、ゲートの前面はほとんど直線上とみ

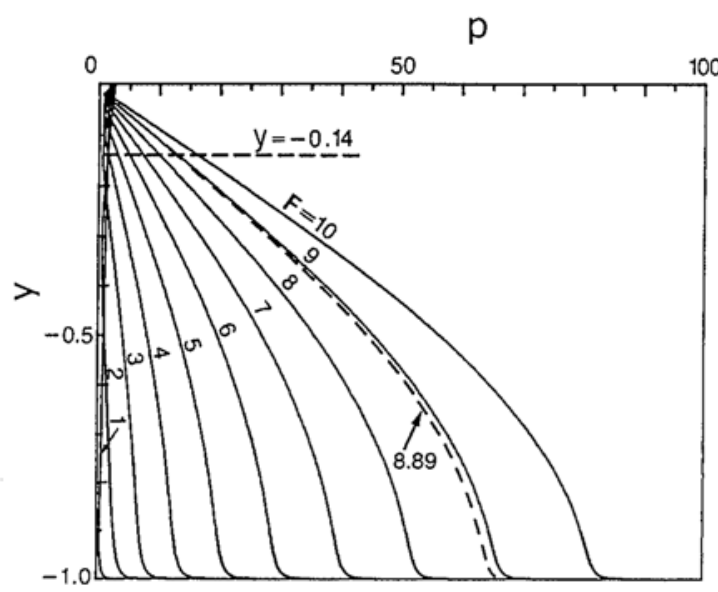

Fig.8 Resultant pressures exerted on the gate from its bottom to the water surface

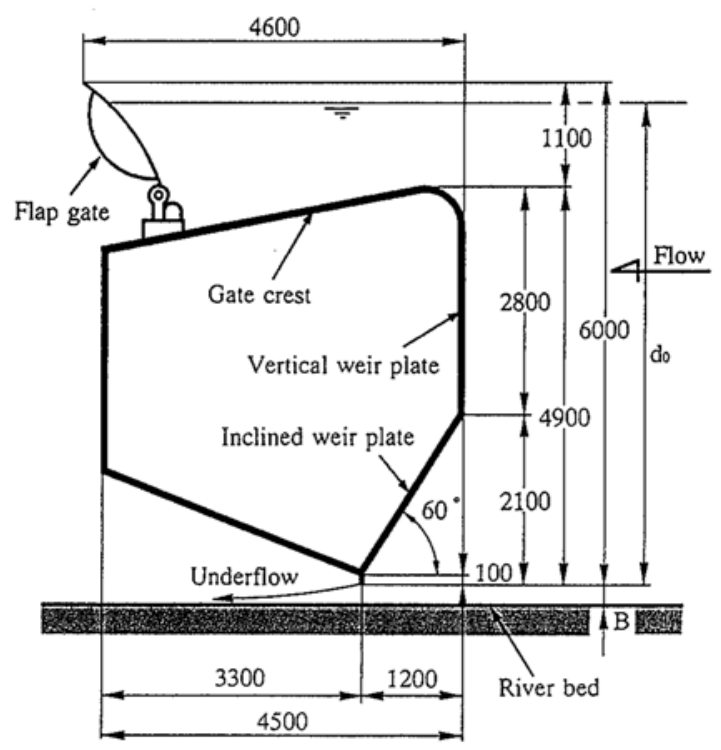

Fig.9 Cross-sectioal view of the full-scale gate (All linear dimensions in $\mathrm{mm}$ )

なすことができる。それゆえ、緹に細長い長径間ゲー トの理論解析結果を応用して、水中での振動数、付加 質量、流体発振係数などをかなり正確に算出すること ができた。しかし、実用されている大形のゲートには、 図 9 に示すように、せき板の傾斜角が $60^{\circ}$ 前後のもの も多い。このような場合には、緃に細長い長径間ゲー トの理論解析結果を単純に応用するわけにはいかない。 このような場合の評価法を早急に検討する必要がある。 さらに、理論解析の結果は放水口開度が微小な場合に のみ有効なむのである。放水流量が比較的大きな場合 の解析法についても检討し、力学的な相似則をさらに 明確なものにする必要がある。 
6.おわりにここでは、水中に沈めて利用する シェル形長径間ゲートの流体関速振動問題について理 論的に評価する一つの近似的な方法を示した。シェル 形長径間ゲートの断面は図 2 に示したように、ゲート 前面には傾斜面があり、ゲート上部は曲線状であると いったように非常に袮雑な形状である。このような境 界を全て蕨密に取扱って理論的な解析を進めることは まず不可能である。ここでは、問題を解けるようにす るためには境界の形状を可能な限り単純化するべきで あるとの基本的な考え方に立って、一枚の直立した平 板が水平方向に振動する場合（縦に細長い長径間ゲー ト）の理論解析結果が応用できるむのと考えた。その 結果、計算值は実測值と良く一致することを示すこと ができた。いずれの場合にも境界の形状を放密に守る べきだとの意見も確かにあるが、境界を単純化して問 題が解けるならばそれに越したことはなく、その結果 が実測との対応で正しいことが検証されるならば、さ らにそれに優るすのはない、と考えている。

ここでは紙面の都合上、水門の振動問題だけに限定 して説明したか、水門以外にも水理槛造物で重要な振 動問題を抱えている例がある。1994年 4 月に高速增殖 妒「もんじゅ」が臨界に達し、運転を開始しているが、 それと同じタイプの高速增殖护「スーパーフェニック
ス（仏国）」において重大な振動問題が発生したこと がある図10に示すように、原子炬壁を冷却するため に低温液体ナトリウムを薄肉円筒せきからいつ流させ ている。そのときに、薄肉円筒せきが上、下流の水面 に発生する定在波と連成して激しい自励振動を引き起 こした。この種の流体関速振動問題に関していくつか の研究報告(列 ${ }^{17)}$ があるか、まだまだその全容が解朋さ れたとは䇾いがたい現状である。今後の早急な理論的 解明が望まれるテーマである。

辈辞実地調查を行うにあたっては㮫丸島アクア システム、成実哲郎氏から多大なこ協力を得た。ここ に、謹んで謝意を表す。

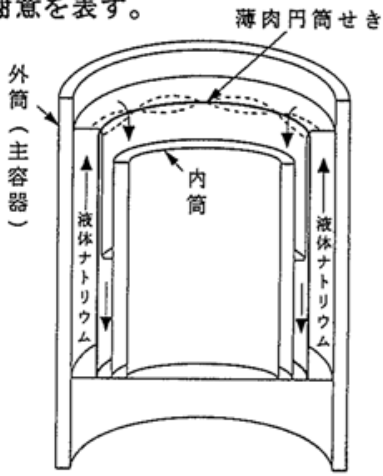

Fig.10 Schematic view of an atomic reactor vessel

参考文献

(1) Davis, C.V. and Sorensen, K.E., Handbook of Applied Hydraulics, 21-1, McGraw-Hill, 1969.

（2）石井・今市: 表面波の発生と速成したテンタゲー 卜系の自励振動、日本機械学会綸文集、第 42 巻 364号、pp. 3853-3861、1975-12.

（３）今市・石井：放水量の変化による夕゙ムのせき止め 水面に生しる波、日本機械学会論文集、第 42 巻 364号、pp. 3929-3941、1975-12.

(4) Ishii, N. and Imaichi, K. : Instability of Elastically Suspendned Tainter-Gate System Caused by Surface Waves on the Reservoir of a Dam, Trans. ASME, J. Fluid Engineering, Ser.I, Vol.99, No.4, pp.699-709, 1977-12.

(5 ) Ishii, N. and Imaichi, K. : Dynamic Instability of Tainter -Gates, In : Pratical Experiences with Flow-Induced Vibrations (ed. Naudascher,E. \& Rockwell.D.), pp.452 $-460,1980$, Berlin, Springer-Verlag.

（6）石井・今市: 表面波の発生と速成したテンタゲー 卜の自励振動 (近似解) 、日本機械学会論文集 B 編、第48巻428号、pp. 640-647、1982-4.

(7) 石井・今市: 眝水池が比較的浅い場合のテンタゲ 一トの自励振動（第 1 報、運動方程式の您出）、 日本機械学会論文集 B 編、第 54 巻 508 号、pp. 3444 -3448、1988-12.

(8) Ishii, N. and Naudascher, E. : A Design Criterion for Dynamic Stability of Tainter Gates, J. Fluids \& Structures, Vol.6, No.1, pp.67-84, 1992.

(9) Ishii, N., Knisely, C.W. and Nakata, A. : Field Study of a Long-Span Shell-Type Gate Undergoing Flow, J. Fluids \& Structures, to appear in 1994.
(10) Ishii, N. and Knisely, C.W. : Flow-Induced Vibration of Shell-Type Long-Span Gates, J. Fluids \& Structures, Vol.6, pp.681-703, 1992.

(11) Ishii, N., Knisely, C.W. and Nakata, A. : Coupled-Mode Vibration of Gates with Simultaneous Over- and Underflow, J. Fluids \& Structures, to appear in May, 1994.

（12）石井・ほか 2 名：長径間ゲートの流体関速振動 （第 1 報、運動方程式の導出）、日本機械学会論 文集 B 編、第53巻495号、pp. 3267-3273、1987-11.

(13) 石井・ほか 3 名：長径間ゲートの流体関速振動 （第 2 報、付加質量之流体減衰係数）、日本機械 学会論文集 B 編、第54巻504号、pp. 1977-1984、 1988-8.

（14）石井・ほか 4 名：長径間ゲートの流体関連振動 （第 3 報、付加質量亡流体減衰係数の検証）、日 本機械学会論文集 B 編、第54巻507号、pp. 3151 3156、1988-11

（15）石井：長径間ゲートの流体関連振動（第 4 報、层 動数比之流体減衰比)、日本機械学会論文集 B 縟、 第56巻531号、pp. 2887-2892、1990-11.

(16) Ishii, N. : Flow-Induced Vibration of Long-Span Gates, (Part I : Model Development), J. Fluids \& Structures, Vol.6 No.5, pp.539-562, 1992.

（17）千葉・木内：薄肉円筒せきの流力弾性不安定振動 に関する実験（不安定振動特性）、日本機械学会 論文集 C 編、第 59 巻 565号、pp. 2600-2605、 1993-9. 